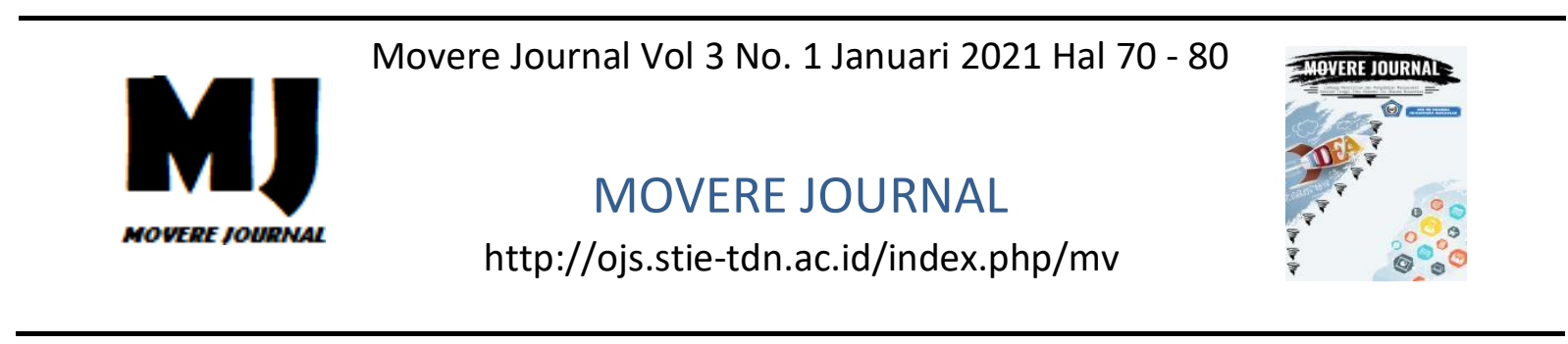

\title{
Analisis Tingkat Pengalaman Kerja dan Fasilitas Kerja Terhadap Kinerja Karyawan PT. Industri Kapal Indonesia (Persero) Makassar
}

\author{
Hendra Gunawan \\ STIE AMKOP Makassar
}

\begin{abstract}
Abstrak : Tujuan dari penelitian ini adalah untuk menganalisis dan mengetahui pengaruh pengalaman kerja terhdapa kinerja dan pengaruh dari fasilitas kerja terhadap kinerja karywan PT. Industri Kapal Indonesia (Persero) Makassar. Responden dalam penelitian ini adalah 173 orang, dengan penarikan sampel sebanyak 63 orang. Model analisis yang digunakan untuk mengetahui pengaruh antar variabel adalah model regresi berganda. Hasil penelitian menunjukkan bahwa pengalaman kerja bepengaruh postif dan signifikan terhadap kjnerja, sedangkan fasilitas kerja berpengaruh positif namun tidak signifikan terhadap kinerja karywan PT. Industri Kapal Indonesia (Persero) Makassar. Hal ini membuktikan bahwa semakin banyak pengalaman kerja dan semakin memadainya fasilitas kerja yang dimiliki oleh karyawan maka kinerja karyawan juga akan semakin baik. Oleh karena itu, sangat diharapkan adanya kelengkapan sarana yang memadai dalam lingkungan kerja agar karyawan dapat menyelesaikan pekerjaannya dengan efektif dan efisien sehingga menghasilkan kinerja yang baik dan berkualitas.
\end{abstract}

Kata kunci : Pengalaman Kerja ; Sarana pendukung ; Kinerja

Abstract : The objective of this study is to analyze and determine the influence of work experience toward the performance and the influence of work facilities toward the performance of employees of PT. Industri Kapal Indonesia (Ltd.) Makassar. Respondent in this study are 173 people and the sample consists of 63 people. The analysis model used to determine the influence between variables is multiple regression models. The results show that work experience has a positive and significant influence toward work performance, whereas work facilities have a positive influence but it is not significant toward the performance of employees of PT. Industri Kapal Indonesia (Ltd) Makassar. This proves that the more work experience and the more adequate work facilities the employees have, the better the employees' performance will be. Therefore, it is expected that there will be adequate facilities in the work environment in order to the employees can accomplish their work effectively and efficiently to create good performance and quality.

Keywords: Work Experience; Supporting facilities; Performance

\section{PENDAHULUAN}

Di era modernisasi saat ini dimana pertumbuhan industri yang semakin pesat menuntut kebutuhan tenaga kerja tingkat menengah yang berpengetahuan dan terampil. Semua orang dituntut untuk lebih 
pintar, kreatif, inovatif, mempunyai keahlian dibidangnya, peka terhadap lingkungan sekitar dan bisa menentukan pekerjaan yang sesuai dengan kehlian dan kemapuan dibidangnya.

Kondisi seperti ini menyebabkan persaingan dalam dunia kerja semakin ketat, sehingga dibutuhkan tenaga kerja yang mempunyai keahlian dan ketrampilan yang dibutuhkan di dunia kerja. Keterampilan dan keahlian seorang tenaga kerja dapat di peroleh melalui pembelajaran di instansi pendidikan atau melalui pelatihan keterampilan di lembaga pelatihan keterampilan.

Pengalaman kerja adalah proses pembentukan pengetahuan atau keterampilan tentang metode suatu pekerjaan karena keterlibatan karyawan tersebut dalam pelaksanaan tugas pekerjaan (Manulang, 1984 : 15). Pengalaman kerja adalah ukuran tentang lama waktu atau masa kerja yang telah ditempuh seseorang dapat memahami tugas - tugas suatu pekerjaan dan telah melaksanakan dengan baik (Ranupandojo, 1984 : 71).

Pengalaman kerja adalah pengetahuan atau keterampilan yang telah diketahui dan dikuasai seseorang yang akibat dari perbuatan atau pekerjaan yang telah dilakukan selama beberapa waktu tertentu (Trijoko, 1980 : 82). Dari uraian tersebut dapat disimpulkan, bahwa pengalaman kerja adalah tingkat penguasaan pengetahuan serta keterampilan seseorang dalam pekerjaannya yang dapat diukur dari masa kerja dan dari tingkat pengetahuan serta keterampilan yang dimilikinya.

Rendahnya kinerja karyawan menjadi issue utama dalam industri manufaktur. Padahal, nyatanya industri manufaktur berperan penting dalam perekonomian Indonesia. Setiap perusahaan yang bergerak dalam industri manufaktur dihadapkan dengan permasalahan yang sama, yaitu sumber daya manusia dengan kinerja yang tidak kompeten. Menurut Mangkunegara (2009), kinerja karyawan merupakan hasil kerja secara kualitas dan kuantitas yang dicapai seorang karyawan dalam melaksanakan tugasnya sesuai dengan tanggung jawab yang diberikan kepadanya. Biasanya, perusahaan melihat kinerja karyawan melalui penilaian oleh atasan atau manajer perusahaan.

\section{TINJAUAN PUSTAKA}

Menurut Rivai (2004) memberikan pandangan spesifik mengenai pengalaman kerja yang diidentikkan dengan masa kerja. Masa kerja yang dimaksud yaitu lama waktu seseorang menduduki jabatan pekerjaannya. Masa kerja yang lama menunjukkan pengalaman yang lebih dari seseorang dengan rekan kerja yang lain. Besar kecilnya pengalaman kerja dapat mempengaruhi seseorang dalam mengelola dan melaksanakan tugas kinerja dan tingkat pendapatan mereka.

Menurut Handoko

(2009:27) menyatakan bahwa pengalaman kerja seseorang menunjukkan jenis-jenis pekerjaan yang telah dilakukan seseorang yang memberikan peluang besar bagi seseorang untuk melakukan pekerjaan yang lebih baik selama jangka waktu tertentu. Semakin luas pengalaman kerja seseorang, semakin terampil seseorang dalam bertindak untuk mecapai tujuan yang telah ditetapkan.

Menurut Sutrisno (2009), pengalaman kerja adalah suatu dasar/acuan seorang karyawan dapat menempatkan diri secara tepat kondisi, berani mengambil resiko, 
mampu menghadapi tantangan dengan penuh tanggung jawab serta mampu berkomunikasi dengan baik terhadap berbagai pihak untuk tetap menjaga produktivitas, kinerja dan menghasilkan individu yang kompeten dalam bidangnya.

Menurut

(Mangkuprawira:2009), menyatakan pengalaman seseorang dalam bekerja merupakan akumulasi dari keberhasilan dan kegagalan serta gabungan dari kekuatan dan kelemahan didalam melaksanakan pekerjaannya. (Gibson:2011) berpendapat orang yang mempunyai pengalaman akan selalu lebih pandai dalam menyikapi dari segala hal daripada mereka yang sama sekali tidak memiliki pengalaman

Pengalaman kerja dapat mempengaruhi kinerja yang dihasilkan oleh karywan. Hal ini didukung dengan teori Robbins dan Timothy (2014) bahwa pengalaman kerja berpengaruh positif terhadap kinerja karyawan. Artinya semakin banyak pengalaman kerja, maka kinerja karyawan semakin tinggi. Sebaliknya semakin sedikit pengalaman kerja, makakinerja karyawan juga semakin rendah.

Pengalaman kerja tidak hanya menyangkut jumlah masa kerja, tetapi lebih dari juga memperhitungkan jenis pekerjaan yang pernah atau sering dihadapi. Sejalan dengan bertambahnya pekerjaan, maka akan semakin bertambah pula pengetahuan dan keterampilan seseorang dalam bekerja. Hal tersebut dapat dipahami karena terlatih dan sering mengulang suatu pekerjaan sehingga kecakapan dan keterampilan semakin dikuasai secara mudah, tetapi sebelumnnya tanpa latihan, pengalaman-pengalaman yang pernah dimiliki bahkan terlupakan.

Fasilitas kerja terkait dengan lingkungan kerja, karena lingkungan kerja juga merupakan fasilitas kerja, dengan adanya lingkungan kerja yang nyaman maka karyawan dapat melaksanakan kerja dengan baik. Menurut Ovidiu (2013) secara sederhana yang dimaksud dengan fasilitas adalah suatu sarana fisik yang dapat memproses atau masukan (input) menuju keluaran (output) yang diingankan. Menurut Rista (2014) Fasilitas adalah penyadia perlengkapan-perlengkapan fisik untuk memberikan kemudahan kepada penggunanya, sehingga kebutuhankebutuhan dari pengguna fasilitas tersebut dapat terpenuhi.

Menurut Bary (2012:67) Fasilitas kerja adalah sebagai sarana yang diberikan perusahaan untuk mendukung jalannya nada perusahaan dalam mencapai tujuan yang ditetapkan oleh pemegang kendali

Menurut Moenir (2011:119) Fasilitas kerja adalah segala jenis peralatan, perlengkapan kerja dan pelayanan yang berfungsi sebagaia alat utama/pembantu dalam melaksanakan pekerjaan, dan juga sosial dalam rangka kepentingan orangorang yang sedang berhubungan dengan organisasi kerja itu atau segala sesuatu yang digunakan, dipakai, ditempati dan dinikmati oleh pengguna. Sejalan dengan penelitian Ramlawati et al. (2020), bahwa fasilitas kerja juga berdampak pada kepuasan kerja karywan.

Sedangakan menurut Lupiyaodi (2006:150) fasilitas kerja adalah sarana pendukung dalam aktivitas perusahaan berbentuk fisik, dan digunakan dalam kegiatan normal perusahaan, memiliki jangka waktu kegunaan yang relatif permananen dan memberikan manfaat untuk masa yang akan datang.

Dari uraian diatas maka dapat disimpulkan bahwa fasilitas kerja adalah sarana dan prasarana yang disiapkan atau 
disediakan oleh perusahaan kepada para karyawan untuk menunjang pekerjaannya agar taecipta produktivitas kerja yang baik demi tercapainya tujuan perusahaan.

\section{Faktor yang Memengaruhi Kinerja Karyawan}

\section{Diri Karyawan}

Kecocokan antara karyawan dengan pekerjaannya menjadi faktor yang terpenting. Bagaimana minat, motivasi, pendidikan, bakat serta karakter karyawan harus diketahui. Hal ini dapat dilakukan dengan diadakannya psikotes dan aptitude tes saat proses menyeleksi karyawan. Pengukuran kemampuan dasar seperti kecepatan reaksi, keterampilan tangan dan sebagainya akan sangat berpengaruh.

\section{Fisik}

Faktor fisik ini mencakup metode kerja, cara kerja, lingkungan fisik, bahan serta peralatan kerja yang digunakan oleh karyawan. Seperti apakah pembagian kerja dilakukan dengan benar, pekerjaan yang berulang-ulang, kontrol pekerjaan yang dilakukan oleh mesin dan munculnya jenuh dan stress yang juga biasanya dialami oleh karyawan perusahaan manufaktur.

\section{Sosial dan Organisasi}

Sosial dan organisasi juga berperan penting dalam kinerja karyawan. Hal ini meliputi pelatihan dan pengembangan karyawan, sistem upah yang benar dan sesuai dengan aturan yang berlaku di Indonesia, kepemimpinan yang baik serta iklim kerja karyawan (Nur 2021)

\section{Cara Penilaian Kinerja Karyawan}

Memang, tidak ada satu rumus kepastian dalam penilaian kinerja karyawan industri manufaktur, tetapi ada beberapa hal yang konstan terjadi dalam perusahaan ini.
Berikut penilaian yang bisa dilakukan oleh bagian personalia atau manajer.

\section{Tingkat Kepuasan Pelanggan}

Pelanggan merupakan prioritas nomor satu bagi industri manapun, pelanggan adalah aset berharga. Pelanggan yang bahagia bisa menjadi duta industri secara tidak langsung karena mereka akan memberitahu orang-orang di sekitarnya. Mengingat peran penting mereka dalam keberlanjutan bisnis, sangat penting jika mereka sepenuhnya puas dengan produk yang ditawarkan.

Sebuah perusahaan industri manufaktur bisa melakukan survei kepuasaan pelanggan secara rutin. Jika pelanggan menilai pengalaman mereka dengan baik, maka itu menjadi penghargaan bagi karyawan. Tetapi sebaliknya, jika pelanggan kurang puas terhadap produk, maka menjadi evaluasi untuk segala tim karyawan di perusahaan. Dimulai dari tim produksi, tim penjualan hingga tim pengiriman.

\section{- Changeover}

Changeover merupakan waktu yang dibutuhkan untuk proses perubahan pada mesin atau jalur produksi. Perusahaan manufaktur bisa menggunakan evaluasi ini untuk mengukur jumlah waktu atau kecepatan yang diperlukan. Hal ini juga tergantung pada efisiensi karyawan dan peralatan, proses dapat berlangsung selama beberapa menit, jam atau berhari-hari.

Changeover yang berhari-hari tidak pernah baik untuk bisnis, jika mereka bertahan selama berhari-hari, maka dapat menghabiskan biaya jutaan bagi perusahaan. Oleh karena itu, penting bagi sebuah perusahaan manufaktur mengevaluasi waktu yang diperlukan dalam changeover agar dapat ditingkatkan. Misalnya, jika peralatan 
yang menjadi masalah, perusahaan dapat beralih menggunakan peralatan yang mudah dipasang dan dikonfigurasikan. Setelah itu, efektivitas karyawan dapat diukur dengan seberapa efisien proses changeover berjalan hingga proses produksi berjalan sepenuhnya.

\section{Pemanfaatan Kapasitas}

Penilaian ini menunjukkan jumlah output yang digunakan perusahaan manufaktur dalam waktu tertentu. Perusahaan yang berjalan dengan kapasitas penuh memiliki pemanfaatan kapasitas $100 \%$. Seorang manajer bisa menggunakan evaluasi pemanfaatan kapasitas untuk memeriksa seberapa baik kinerja departemen yang bertanggung jawab. Perlu dipertanyakan apakah parameternya berada di bawah persentase yang diharapkan.

\section{Produksi atau Jadwal Pencapaian}

Ini merupakan ukuran seberapa sering perusahaan mencapai target produksinya dalam waktu yang ditentukan. Penilaian dapat menggunakan persentase produksi terjadwal untuk menunjukkan output secara aktual. Jika angka rendah, berarti tim produksi tidak dapat merencanakan produksi dengan baik atau mesin tidak bekerja secara optimal.

\section{Produksi yang Cacat}

Ini merupakan sebuah evaluasi untuk menilai tim produksi. Seorang manajer dapat melihat seberapa banyak produk dalam industri yang dihasilkan dengan barang yang cacat produksi. Ketika produksi dengan produk yang cacat tinggi, maka dapat disimpulkan bahwa kualitas kinerja karyawan di tim produksi juga rendah.

\section{Tingkat Absensi}

Ketidakhadiran dan kinerja berjalan beriringan. Menurut beberapa penelitian, karyawan yang sangat terlibat dan termotivasi membutuhkan hari sakit yang lebih sedikit, yaitu 37\%. Selain itu, karyawan yang sering melakukan absen juga bisa menurunkan produktivitas perusahaan dengan kualitas kinerja yang rendah. Hal ini juga bisa ditinjau dengan menggunakan aplikasi absensi agar penilaian dilakukan lebih cepat dan akurat. Bisa dikatakan Komitemen juga sangat berpengarh terhadap kinerja karyawam. (Rostini et al. 2020)

\section{- Lembur per Karyawan}

Selain absensi, perhitungan lembur juga bisa dilakukan untuk penilaian kinerja karyawan. Karyawan yang bersedia bekerja lembur sering termotivasi dan akan berkontribusi lebih pada perusahaan. Sebuah perusahaan manufaktur dapat memeriksa berapa banyak upaya yang dilakukan setiap karyawan terhadap perusahaan dengan menghitung total jam lembur mereka. Sebuah perusahaan dapat menggunakan sebuah software yang memudahkan perusahaan untuk menghitung jam lembur karyawan.

\section{Tujuan Penilaian Kinerja Karyawan}

Tujuan dari menilai karyawan yaitu untuk mengukur kinerja karyawan. Biasanya, penilaian ini selalu dilakukan dalam industri perusahaan manufaktur sehingga perusahaan mengetahui apakah serangkaian faktor dari diri karyawan, faktor fisik serta faktor sosial dan organisasi karyawan cocok dengan pekerjaan karyawan itu sendiri.

\section{- Kekuatan dan Kelemahan Karyawan}

Perusahaan manufaktur harus terus menerus menilai karyawannya agar mengetahui kekuatan dan kelemahan yang dimiliki oleh karyawan dalam perusahaannya. Hal ini penting untuk proses perencanaan tenaga kerja ke depannya. 


\section{Pelatihan dan Pengembangan}

Setelah mengetahui kekuatan dan kelemahan yang dimiliki karyawan, selanjutnya dapat diadakan pelatihan serta pengembangan untuk karyawan. Dengan mengetahui kelemahan yang dialami oleh mayoritas karyawan atau bagian tim tertentu, maka dapat ditentukan pelatihan yang dibutuhkan. (Yasin et al., 2019)

\section{- Sistem Penghargaan}

Pengukuran kinerja karyawan melalui penilaian merupakan komponen dari struktur kompensasi kebanyakan perusahaan. Peringkat yang diterima karyawan dapat mempengaruhi jumlah gaji atau kenaikan upah karyawan. Tentu, hasil kinerja terbaik akan mendapat tambahan bonus lebih dari perusahaan.

\section{METODE PENELITIAN}

\section{A. Jenis Penelitian}

Jenis penelitian yang digunakan adalah penelitian kuantitatif. Jenis penelitian kuantitatif adalah penelitian yang berdasarkan pada filsafat positivisme, yang digunakan untuk meneliti pada populasi atau sampel tertentu. Pengumpulan data menggunakan instrument penelitian, analisis dan bersifat kuantitatif statistic, dengan tujuan untuk menguji hipotesis yang telah ditetapkan. (sugiyono, 2014:11)

\section{B. Lokasi dan jadwal penelitan}

Penelitian dilakukan di PT. Industri Kapal Indonesia (Persero) Makassar. Waktu yang di butuhkan dalam melakukan penelitian ini kurang lebih 1 bulan lamanya

\section{Populasi Dan Sampel}

\section{Populasi}

Populasi adalah wilayah generalisasi atas obyek/subyek yang mempunyai kualitas dan karakteristik tertentu yang di tetapkan oleh peneliti untuk dipelajari dan kemudian ditarik kesimpulannya.

Dengan demikian populasi yang akan digunakan penulis dalam penelitian ini adalah seluruh karyawan PT. Industri Kapal Indonesia (Persero) Makassar yang berjumlah 173 karyawan.

\section{Sampel}

Menurut Sugiyono (2010:118) Sampel adalah sebagian dari jumlah dan karakteristik yang dimiliki oleh populasi tersebut. Menurut Sugiyono (2008:118) simple random samling karena pengambilan anggota sampel dari populasi dilakukan secara acak tanpa memperhatikan starata yang ada dalam populasi itu.

Metode yang digunakan dalam memetukan jumlah sampel dalam penelitian ini adalah menggunakan rumus slovin sebagai berikut.

Dimana :

$$
n=\frac{N}{1+N e^{2}}
$$

$\mathrm{N}$ : Populasi

$\mathrm{n}$ : Besar Sampel

D : Tingkat Kepercayaan

$$
\begin{gathered}
n=\frac{N}{1+N(e)^{2}} \\
n=\frac{173}{1+173(0.1)^{2}} \\
n=\frac{173}{1+173(0.01)} \\
n=\frac{173}{1+1,73} \\
n=\frac{173}{2,73} \\
n=64,3 \\
n=63
\end{gathered}
$$

Berdasarkan perhitungan yang telah dilakukan dengan menggunakan rumus diatas, diperoleh 63 responden dari 173 populasi karyawan PT. Industri Kapal Indonesia (Persero) Makassar. 


\section{- Instrument Penelitian}

Dalam penelitian ini instrument yang digunakan adalah wawancara dan kuesioner.Menurut sugiyono (2014:135) instrument penelitian adalah suatu alat yang digunakan mengukur fenomena alam maupun sosial yang di amati. Dalam penelitian ini jawaban yang diberikan oleh responden kemudian di beri skor dengan mengacu pada skala likert. Likert adalah skala yang digunakan untuk mengukur sikap, pendapat, dan persepsi seseorang tentang suatu objek atau fenomena tertentu.

\section{- Tehnik Pengumpulan Data}

Untuk memperoleh data serta informasi ang diperlukan penulis melakukan tehnik sebagai berikut :

a. Pengamatan (observation) adalah kegiatan pengumpulan data dengan melakukan penelitian langsung terhadap kondisi lingkungan obyek penelitian yang mendukung kegiatan penelitian, sehinnga didapat gambaran secara jelas tentang kondisi obyek penelitian tersebut. (Syofian Siregar, 2015:19)

b. Wawancara yaitu pengumpulan data yang dilakukan dengan cara melakukan dialog secara langsung dengan karyawan.

c. Kusioner (Quesioner)merupakan tehnik pengumpulan data yang dilakukan dengan cara memberi serangkaian pertanyaan tertulis kepada responden untuk dijawab, penelitiakan menguraikan jawaban responden yang dikelompokkan dalam kategori dengan skala likert.

\section{HASIL ANALISIS DAN PEMBAHASAN}

\section{A. Pengaruh Pengalaman Kerja Terhadap Kinerja}

Berdasarkan output SPSS, hasil penelitian menunjukkan bahwa pengalaman kerja berpengaruh positif dan signifikan terhadap kinerja karyawan pada PT. Industri Kapal Indonesia (Persero) Makassar. Hipotesisnya yaitu Pengalaman Kerja berpengaruh positif dan signifikan terhadap kinerja karyawan pada PT. Industri Kapal Indonesia Makassar (Persero). Hal ini ditunjukkan nilai $\mathrm{t}$ hitung $>\mathrm{t}$ tabel, (4.334 > 2.00030 ), atau sig $0.000<0.05$, berarti variabel pengalaman kerja berpengaruh positif dan signifikan terhadap kinerja karyawan pada PT. Industri Kapal Indonesia (Persero) Makassar.

Alasannya dapat terlihat pada kuesioner yang di ajukan pada responden dengan mayoritas menjawab sangat setuju pada pernyataan pertama jawaban responden sangat setuju sangat tinggi, indikator pada pernyataan tersebut adalah Pengalaman kerja yang saya peroleh selama masa kerja membuat hasil kerja saya semakin berkualitas, itu menandakan bahwa karyawan PT. Industri Kapal Indonesia (Persero) Makassar rata-rata mampu memperoleh hasil kerja yang berkualitas. Hal ini berarti jika karyawan memiliki penglaman kerja yang memumpuni dalam menyelesaikan pekerjaannya maka akan sangat berpengaruh terhadap kinerja karyawan tersebut.

Dengan demikian dapat disimpulkan bahwa semakin lama masa kerja dan semakin banyak pengalaman kerja maka kinerja yang dihasilkan juga akan semakin baik dan berkualitas. Semakin sering seseorang mengulangi suatu pekerjaan maka semakin bertambah kecakapan dan pengetahuannya terhadap satu bidang pekerjaan tersebut, sehingga dapat memberikan konribusi yang baik terhadap tugas-tugas dan fungsinya. 


\section{B. Pengaruh Fasilitas Kerja Terhadap Kinerja}

Berdasarkan output SPSS, hasil penelitian menunjukkan bahwa fasilitas kerja berpengaruh positif dan tidak signifikan terhadap kinerja karyawan PT. Industri Kapal Indonesia (Persero) Makassar. Hipotesisnya yaitu fasilitas kerja berpengaruh positif dan signifikan terhadap kinerja karyawan PT. Industri Kapal Indonesia (Persero) Makassar di tolak. Hal ini ditunjukkan nilai thitung lebih besar dari $t$ tabel (1,763 > 2.00030), atau sig, $(0,083<$ $0,05)$. Berarti variabel fasilitas kerja berpengaruh positif dan tidak signifikan terhadap kinerja karyawan PT. Industri Kapal Indonesia (Persero) Makassar.

Alasannya dapat dilihat pada kuesioner yang diajukan kepada responden dengan mayoritas menjawab sangat tidak setuju pada pernyataan pertama jawaban responden sangat tidak setuju sangat tinggi, indikator pada pernyataan tersebut adalah Fasilitas kerja yang di berikan perusahaan tidak memadai. Itu menandakan bahwa karyawan PT. Industri Kapal Indonesia (Persero) Makassar rata-rata belum memiliki fasilitas kerja yang mendukung dan memadai yang diberikan perusahaan. Hal ini berarti dengan tersedianya fasilitas kerja yang memadai dalam melakukan sebuah pekerjaan maka akan sangat berpengaruh terhadap kinerja yang dihasilkan. Hal ini tidak sejalan dengan penelitian Anam et al.,(2017) yang meyatakan bawa fasilitas kerja berpengaruh positif dan signifikan terhdap kinerja karyawan.

Dengan demikian dapat disimpulkan bahwa fasilitas kerja sangat diperlukan untuk meningkatkan kinerja karyawan. Semakin lengkap dan semakin memadainya fasilitas kerja yang diberikan maka karyawan dapat menyelesaikan pekerjaannya dengan efektif dan efisien sehingga menghasilkan kinerja yang baik dan berkualitas.

\section{Pengaruh Pengalaman Kerja dan Fasilitas Kerja Terhadap Kinerja Karyawan}

Berdasarkan hasil output SPSS, hasil penelitian menunjukkan bahwa ada pengaruh positif dan signifikan secara bersama-sama antara Pengalaman Kerja dan Fasilitas Kerja Terhadap Kinerja Karyawan PT. Industri Kapal Indonesia (Persero) Makassar. Hipotesisnya yaitu pengalaman kerja dan fasilitas kerja secara bersama-sama berpengaruh positif dan signifikan terhadap kinerja karyawan PT. Industri Kapal Indonesia (Persero) Makassar. Hal ini ditunjukkan dengan uji ANOVA atau Uji F dapat dilihat $\mathrm{F}$ hitung 12.740 lebih besar dari F tabel yaitu 3.15 dengan signifikan 0,000 . Karena nilai signifikan jauh lebih kecil dari 0,05 maka model regresi dapat digunakan untuk memprediksi kinerja atau dapat dikatakan kedua variabel pengalaman kerja dan fasilitas kerja secara bersama-sama berpengaruh positif dan signifikan terhadap kinerja karyawan PT. Industri Kapal Indonesia (Persero) Makassar.

Alasannya dapat dilihat pada tanggapan responden yang mayoritas responden sangat setuju dengan pernyataan-pernyataan yang terdapat pada kuesioner yang diajukan dan merupakan indikator-indikator dari pengalaman kerja dan fasilitas kerja terhadap kinerja karyawan maka akan meningkatkan perspektif yang dapat menimbulkan hasil positif yang nantinya akan mempengaruhi kinerja karyawan. Hal ini berarti semakin banyak pengalaman kerja dan semakin memadainya fasilitas kerja 
yang dimiliki oleh karyawan maka kinerja karyawan juga akan semakin baik. Begitu pula sebaliknya.

\section{KESIMPULAN DAN SARAN}

\section{A. Kesimpulan}

Penelitian ini dimaksudkan untuk mengetahui pengaruh pengalaman kerja dan fasilitas kerja terhadap kinerja karyawan PT. Industri Kapal Indonesia (Persero) Makassar. Berdasarkan hasil uraian penelitian dan pembahasan maka dapat ditarik kesimpulan dari penelitian ini adalah:

a. Dari hasil uji parsial yang dilakukan pada hipotesis pertama, dapat disimpulkan bahwa semakin lama masa kerja dan semakin banyak pengalaman kerja maka kinerja yang dihasilkan juga akan semakin baik dan berkualitas. Semakin sering seseorang mengulangi suatu pekerjaan maka semakin bertambah kecakapan dan pengetahuannya terhadap satu bidang pekerjaan tersebut, sehingga dapat memberikan konribusi yang baik terhadap tugas-tugas dan fungsinya.

b. Dari hasil uji parsial yang dilakukan pada hipotesis kedua, dapat disimpulkan bahwa fasilitas kerja tidak berpengaruh signifikan terhadap kinerja karyawan., olehnya itu diperlukan kengkapan sarana dan fasilitas yang memadai agar karyawan dapat menyelesaikan pekerjaannya dengan efektif dan efisien sehingga menghasilkan kinerja yang baik dan berkualitas.

c. Dari hasil uji Simultan yang dilakukan pada hipotesis ketiga, bahwa ada pengaruh positif dan signifikan antara Pengalaman Kerja dan Fasilitas Kerja Terhadap Kinerja. Hal ini berarti semakin banyak pengalaman kerja dan semakin memadainya fasilitas kerja yang dimiliki oleh karyawan maka kinerja karyawan juga akan semakin baik

\section{B. Saran}

Berdasarkan hasil penelitian tentang pengaruh pengalaman kerja dan fasilitas kerja terhadap kinerja karyawan PT. Industri Kapal Indonesia (Persero) Makassar, maka peneliti memberikan saran yaitu:

a. Bagi PT. Industri Kapal Indonesia (Persero) Makassar, agar lebih memperhatikan faktor pengalaman kerja dalam upaya untuk meningkatkan kinerja karyawan. Cara yang dapat dilakukan adalah dengan mengadakan pelatihan dan pendidikan terhadap karyawan. Fasilitas kerja karyawan juga perlu mendapatkan perhatian dari pihak perusahaan dengan cara memenuhi apa yang di harapkan oleh karyawan dalam hal meningkatkan kinerja. Dengan tujuan menciptakan suasana kerja yang nyaman dan terciptanya keefektifan serta efisien dalam bekerja.

b. Bagi peneliti selanjutnya yang tertarik untuk meneliti aspek pengalaman kerja, fasilitas kerja, serta kinerja karyawan diharapkan untuk mengembangkan penelitian ini dengan menggunakan populasi dan sampel yang lebih luas agar hasil penelitian lebih teruji keandalannya.

\section{DAFTAR PUSTAKA}

(1) Anggrainy, Ika Fauzi. 2018. Pengaruh Fasilitas Kerja, Disiplin Kerja Dan SKompetensi Kerja Imlikasinya Pada Prestasi Kerja Pegawai Negeri Sipil Badan Kepegawaian Pendidikan Dan 
Pelatihan Provinsi Aceh. Fakultas Ekonomi Dan Bisnis Universitas Syiah Kuala Banda Aceh. Jurnal

(2) Anam Khoirul, Edy Rahardja, 2017. Pengaruh Fasilitas Kerja, Lingkungan Kerja Non Fisik Dan Kepuasan Kerja Terhadap Kinerja Karyawan. Diponegoro Journal of Management 6(4); 502-512

(3) Bintaro \& Daryanto. 2107. Manajemen Penilaian Kinerja Karyawan. Yogyakarta: Pernerbit Gaya Media

(4) Ghizali, Imam. 2011. Aplikasi Analisis Mulivarate Dengan Program SPSS. Semarang: Badan Penerbit Universitas Diponegoro

(5) Hasibuan, Malayu. 2017. Manajemen Sumber Daya Manusia. Edisi Revisi. Jakarta: PT. Bumi Aksara

(6) Itafia, Yanti. 2014. Pengaruh Pengalaman Kerja Dan Kepuasan Kerja Terhadap Produktuvitas Kerja Karyawan Pada Industry Tenun. Fakultas Ekonomi Universitas Pendidikan Ganeeha Singaraja. Jurnal

(7) Maulana, Moh. Farhan. 2016. Analisis Pengaruh Gaji, Tunjangan Dan Fasilitas Kerja Karyawan Pabrik Roti Universal (Bayu Bagus) Baron Nganjuk. Fakultas Ekonomi Universitas Nusantara Pgri Kediri. Skripsi

(8) Nisa, Chairun. 2018. Pengaruh Fasilitas Kerja Dan Lingkungan Kerja Terhadap Kinerja Karyawan PT. Indoking Aneka Agar-Agar Industry Medan. Fakultas Ekonomi Dan Bisnis Universitas Medan Area. Skripsi
(9) Nur, A. 2021. "Transglobal Leadership as a Driver for Increasing the Employee Performance." International Journal of Organizational Leadership 10(1):54-71. doi: 10.33844/ijol.2021.60517.

(10) Octavianus, Wungow Raymond. 2018. Pengaruh Pengalaman Kerja Dan Pelatihan Kerja Terhadap Kinerja Karyawan PT. Telkom Indonesia Cabang Manado. Fakultas Ekonomi Dan Bisnis Universitas Sam Ratulangi Manado. Jurnal

(11) Rahmianti. 2018. Pengaruh Kompetensi Dan Pengalaman Kerja Terhadap Prestasi Kerja Karyawan Pada Finansia Multi Finance Di Kota Makassar. Fakultas Ekonomi Dan Bisnis Islam Universitas Islam Negeri Alauddin Makassar. Skripsi.

(12) Ramlawati, R., E. Trisnawati, N. Yasin, and K. Kurniawaty. 2020. "External Alternatives, Job Stress on Job Satisfaction and Employee Turnover Intention." Management Science Letters 11(2):511-18. doi: 10.5267/j.msl.2020.9.016.

(13) Rostini, R., W. Souisa, R. Masmarulan, and N. Yasin. 2020. "Competitiveness Development, Learning Orientation, Entrepreneurial Commitment and Business Performance in the Silk Industry." Management Science Letters 11(3):903-8. doi:10.5267/j.msl.2020.10.008 
(14) Sugiyono. 2014. Metode Penelitian

Kuantitatif, Kualitatif. Bandung: Alfabeta

(15) Sugiyono. 2008. Metode Penelitian Kuantitatif, Kualitatif. Bandung: Alfabeta

(16) Sutrisno, Edy. 2017. Manajemen Sumber Daya Manusia. Jakarta: Paramedia Grup
(17) Yasin, N. A., Ridjal, S., \& Jjufri, M. 2019. "Human Capital and Entrepreneurship and Their Impact on the Productivity of Traditional Craftsmen." Revista ESPACIOS 40(04). 